\title{
Accrual-based accounting system versus cash-based accounting: An empirical study in municipality organization
}

\author{
Hossein Mohammad Pour Zarandi ${ }^{\mathrm{a}}$, Esmaeel Ghafari ${ }^{\mathrm{b}}$, Mahbobeh $\operatorname{Arab}^{\mathrm{c}}$ and Seyed Mohsen \\ Tabatabaei Mozdabadi ${ }^{\text {d }}$
}

${ }^{a}$ Postdoctoral of Economic Science, Tehran, Iran

${ }^{b} \mathrm{PhD}$ student of Economy and Environment, North Tehran Branch, Islamic Azad University Lecturer, Tehran, Iran

${ }^{c}$ Master of Accounting, Islamic Azad University, Tehran

${ }^{d}$ Master of Educational Administration, lecturer of the university of Applied Science and Technology,, Tehran, Iran

\section{H R O N I C L E}

Article history:

Received April 23, 2012

Received in revised format

26 October 2012

Accepted 28 October 2012

Available online

October 292012

Keywords:

Accrual-based accounting

Cash-based accounting

Informative system

\section{A B S T R A C T}

There are many cases, where we may wish to choose a good accounting system and would like to learn how they work and the advantages and disadvantages of each so we can choose the better one for a business. In this paper, we present an empirical survey to understand whether we can choose accrual or cash accounting system. The proposed study designs a questionnaire among 220 experts in area of accounting affairs. The survey considers four sub hypotheses and one main hypothesis to see whether there are reliable rules and regulations in accrual-based accounting compared with cash accounting or not. Similarly, the survey investigates whether accrual-based accounting is more informative, comprehensive and provides better comparative results compared with cash accounting. The results indicate that accrual-based account performs better in terms of all mentioned criteria and it is a better method for managing accounting affairs compared with cash accounting systems.

\section{Introduction}

The cash method and the accrual method are the two important techniques of keeping track of a business's income and expenses (Caccia et al., 2006; He et al., 2008; Krom \& Williams, 2011). There are many cases, where we may wish to choose a good accounting system and would like to learn how they work and the advantages and disadvantages of each so we can choose the better one for a business. The cash method is one of popular methods of accounting for small businesses where income is not counted until cash or a check is received, actually and expenses are not counted until they are paid, practically. Under the accrual method, all financial transactions are counted when the order is made, the items are delivered, or the services happen, regardless of when the receivables are actually received or payments are getting paid. In other words, income is considered when the sale *Corresponding author.

E-mail addresses: esghafari@yahoo.com (E. Ghafari) 
happens, and expenses are counted when we receive the goods or services and we do not need to wait until we see the money, or actually make the necessary payments to record a transaction. Fig. 1 shows some of the advantages of accrual system.

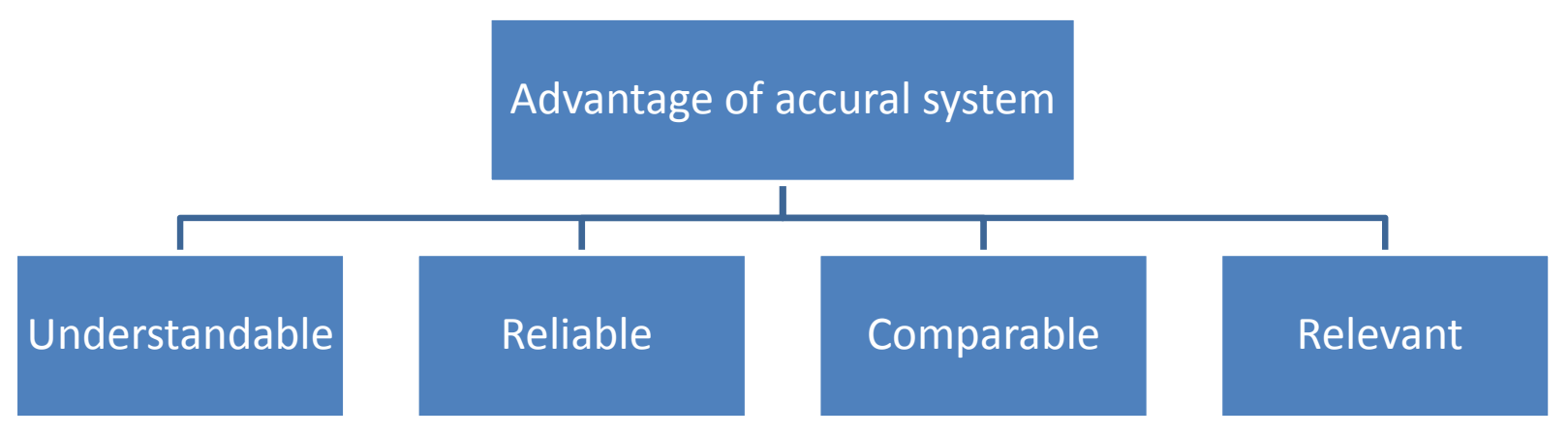

Fig. 1. The advantage of having accrual system

Accrual systems have become popular in European countries and for instance, the transition from cash to accruals accounting for UK central government departments was initiated in the early 1990s and the accomplishment happened within a ten year period. At that time, there were clear indications that analogous changes, following a similar timeline, would happen in the Republic of Ireland (RoI). Kwon (1989) investigated that that accrual accounting is superior to cash-basis accounting in terms of costs. The main reason is described that accrual accounting information more fully reflects the overall impacts of managerial actions or endeavors on future cash flows than cash flow realizations in any given period. Therefore, accrual accounting information is more effective than cash-basis accounting information for both motivating managers to expend efforts and sharing risks under moral hazard.

According to Hyndman and Connolly (2011), the movement from cash to accruals accounting by many governments is viewed as an idea of an ongoing New Public Management agenda designed to reach a more business-like and performance-focused public sector. Accruals accounting normally provides us more appropriate data for decision makers and eventually helps us to have a more effective public sector. Hyndman and Connolly (2011) considered why a functioning accruals system was built in the UK whereas in the RoI the change to accruals accounting was a 'road not taken'.

Cohen and Zarowin (2010) demonstrated that SEO firms involved in real activities manipulation, and the decline in post-SEO performance due to the real activities management was more severe than that due to accrual management. They also explained that post-SEO operating underperformance was driven not just by accrual reversals, but also reflected the real consequences of operational decisions made to manage earnings. They explained how firms' choices of real versus accrual-based earnings management activities around SEOs different predictably as a function of the firm's capability to use accrual management and the costs of doing so.

Ortegren and Reed (1997) discussed that the use of Statement of Financial Accounting Standard [SFAS] No. 106 needs the accrual of the expected costs of postretirement benefits. They addressed how to resolve conflicts between the specific guidance of an original pronouncement of the Financial Accounting Standards Board and the broader application of the accrual accounting model. GårsethNesbakk (2011) considered a case study of an accrual accounting change attempt at central government level in Norway where the case represented alternative accrual accounting solutions. They examined why and in what form alternative accounting thought emerges, and what this means for accounting theory. As an example, they illustrated how the debits represent something new and interrelations with other accounting environments, whereas the way of accounting for credits helped to preserve internal authority, capital and organizational structures. 
Badertscher et al. (2012) investigated discretionary accounting choices and the predictive capability of accruals with respect to future cash flows. They explained that originally reported earnings and accrual components were normally less predictive of future cash flows compared with the restated numbers but they reported the opposite as an achievement for firms classified as making discretionary accounting choices for opportunistic meet-or-beat reasons.

Falkman and Tagesson (2008) explained that the regulation of Swedish municipal accounting had undergone fundamental changes. In accordance with the legislation in that country, a standard-setting body was adjusted, with responsibility for development and interpretation of generally accepted accounting rules and regulations for municipal accounting. The primary objectives of the legislation and reform were to suppress 'creative' accounting and to increase the level of harmonization and comparability. Their results explained that the reform had had a very limited effect on accounting practice and it was not fairly compliance with accounting standards. This result was in line with the assumptions of positive accounting theory but the study concluded that there were differences among the preparers, which could be described by institutional theory.

Battalio et al. (2012) demonstrated that the vast majority of investors ignore value-relevant accruals information but those investors who initiate trades of at least 5,000 shares will more likely to transact in the proper direction. These investors trade based on accruals information only when the previously-announced earnings signal indicates to be positive. On the other hand, those investors initiating the smallest trades appeared to respond to accruals in the wrong direction, but this study suggested this behavior was explained by their attraction to attention-grabbing stocks. They also reported that those who trade on accruals information had enough market power to mitigate the accruals anomaly.

Peng (2011) investigated the relationship between accruals quality and the usefulness of accounting earnings in incentive contracting. The study indicated that better accruals quality was associated with a higher weight on earnings in compensation contracts, which recommends that accruals quality overall could reduce the noise in earnings. Peng (2011) also reported that the positive association between accruals quality and the weight on earnings was mainly driven by innate accruals quality rather than discretionary accruals quality.

Chaney et al. (2011) performed and investigation on the quality of accounting information in politically connected firms and concluded that because of a lesser help to respond to market pressures to increase the quality of information, connected companies can afford disclosing reduce quality accounting information. More specifically, lower quality reported earnings was associated with a higher cost of debt only for the non-politically connected firms in the sample.

In this paper, we present an empirical study to see whether an accrual-based accounting can perform better than cash-based accounting system. The proposed study of this paper is implemented for municipality of Tehran, Iran. The proposed study of this paper first presents details of all hypotheses in section 2 and the results of our investigation are presented in section 3. Finally, concluding remarks are given in the last to summarize the contribution of the paper.

\section{The proposed model}

In this section, we present details of our proposed study for comparing accrual-based accounting versus cash accounting system. The study considers one main hypothesis along with four sub hypotheses.

There are better financial Accounting characteristics in accrual-based accounting than cash payment method in municipality organization of city Tehran. This main hypothesis can be investigated in terms of four other hypotheses as follows, 
1. There are more reliable rules and regulations in accrual-based accounting compared with cash method.

2. Accrual-based accounting method maintains more understandable concepts.

3. There are more relevant information in accrual-based accounting compared with cash method.

4. There are better comparative results in accrual-based accounting compared with cash method.

In order to test the proposed main and sub hypotheses of this paper, we have designed a questionnaire in Likert scale from one to five. The questionnaire were first distributed among 30 experts to verify the validity of the questions and Cronbach alpha (Cronbach, 1951) has been calculated as 0.882, which is well above the minimum acceptable level of 0.70 . We have also verified normality of questions based on different statistical tests. All hypotheses have been verified based on binomial and t-student tests. The sample size has been determined based on the following sampling technique,

$n=\frac{N \times z_{\alpha / 2}^{2} \times p \times q}{\varepsilon^{2} \times(N-1)+z_{\alpha / 2}^{2} \times p \times q}$,

where $N$ is the population size, $p=1-q$ represents the yes/no categories, $z_{\alpha / 2}$ is CDF of normal distribution and finally $\varepsilon$ is the error term. Since we have $p=0.5, z_{\alpha / 2}=1.96$ and $N=2200$, the number of sample size is calculated as $n=220$.

\section{The results}

We first use binomial test to examine the main and sub hypotheses. Table 1 shows the results,

Table 1

The results of testing different hypotheses based on binomial test

\begin{tabular}{|c|c|c|c|c|c|}
\hline Hypothesis & For & $\%$ & Against & $\%$ & P-value \\
\hline Sub-hypothesis 1 & 217 & 0.99 & 3 & 0.01 & 0.00001 \\
\hline Sub-hypothesis 2 & 218 & 0.99 & 2 & 0.01 & 0.00001 \\
\hline Sub-hypothesis 3 & 217 & 0.99 & 2 & 0.01 & 0.00001 \\
\hline Sub-hypothesis 4 & 215 & 0.99 & 2 & 0.01 & 0.00001 \\
\hline Main hypothesis & 212 & 0.99 & 2 & 0.01 & 0.00001 \\
\hline
\end{tabular}

Based on the results of Table 1, we can conclude that both main and sub-hypotheses of this survey have been confirmed, which means accrual-based accounting method provides better information on accounting system, it is more reliable and understandable and leads us to have more commitment transactions. In other words, there are better financial accounting characteristics in accrual-based accounting method than cash accounting method in municipality organization of city Tehran. The other method for testing the proposed hypotheses of this survey is to use t-student and Table 2 shows details of our survey.

\section{Table 2}

Details of our investigation on testing accrual-based accounting method versus cash accounting

\begin{tabular}{llclcc}
\hline Hypothesis & Mean & Standard deviation & t-student & Degree of freedom & P-value \\
\hline Sub.1 & 4.28 & 0.39 & 48.60 & 219 & 0.0000 \\
Sub.2 & 4.31 & 0.43 & 44.66 & 219 & 0.0000 \\
Sub.3 & 4.18 & 0.39 & 45.31 & 218 & 0.0000 \\
Sub.4 & 4.31 & 0.41 & 46.9 & 216 & 0.0000 \\
\hline Main & 4.27 & 0.36 & 51.80 & 213 & 0.0000 \\
\hline
\end{tabular}


As we can observe from the results of Table 2, all hypotheses of this survey have been confirmed when the level of significance is one percent. This means that people who participated in our survey strongly believe that accrual-based accounting system is superior to cash accounting system in terms of reliability, comprehensibility, informatively leading to conclude to recommend accrual-based accounting system for municipality of Tehran.

\section{Conclusion}

In this paper, we have presented an empirical investigation to find out whether accrual-based accounting provides better system compared with cash-based accounting system in terms of providing reliable, informative, comparable and comprehensive results. The proposed study has been implemented among 220 experts who worked for municipality of city of Tehran and the results indicated that accrual-based accounting indeed provide superior system compared with regular cashbased system.

\section{Acknowledgement}

The authors would like to thank the municipality of Tehran for cordially cooperating for the accomplishment of this survey. We are also grateful for the comments made on earlier version of this paper by anonymous referees.

\section{References}

Badertscher, B.A., Collins, D.W., \& Lys, T.Z. (2012). Discretionary accounting choices and the predictive ability of accruals with respect to future cash flows. Journal of Accounting and Economics, 53(1-2), 330-352.

Battalio, R.H., Lerman, A., Livnat, J., Mendenhall, R.R. (2012). Who, if anyone, reacts to accrual information? Journal of Accounting and Economics, 53(1-2), 205-224.

Caccia, L., \& Steccolini, I. (2006). Accounting change in Italian local governments: What's beyond managerial fashion?. Critical Perspectives on Accounting, 17(2-3), 154-174

Chaney, P.K., Faccio, M., \& Parsley, D. (2011). The quality of accounting information in politically connected firms. Journal of Accounting and Economics, 51(1-2), 58-76.

Cohen, D.A., \& Zarowin, P. (2010). Accrual-based and real earnings management activities around seasoned equity offerings. Journal of Accounting and Economics, 50(1), 2-19.

Cronbach, L. J. (1951). Coefficient alpha and the internal structure of tests. Psychometrika, 16(3), 297-334.

Falkman, P., \& Tagesson, T. (2008). Accrual accounting does not necessarily mean accrual accounting: Factors that counteract compliance with accounting standards in Swedish municipal accounting. Scandinavian Journal of Management, 24(3), 271-283

Gårseth-Nesbakk, L. (2011). Accrual accounting representations in the public sector-A case of autopoiesis. Critical Perspectives on Accounting, 22(3), 247-258.

He, H., El-Masry, E., \& Wu, Y. (2008). Accounting conservatism of cross-listing firms in the preand post-Sarbanes Oxley periods. Advances in Accounting, 24(2), 237-242

Hyndman, N., \& Connolly, C. (2011). Accruals accounting in the public sector: A road not always taken. Management Accounting Research, 22(1), 36-45.

Krom, C.L., Williams, S.V. (2011). Tell me a story: Using creative writing in introductory accounting courses to enhance and assess student learning. Journal of Accounting Education, 29(4), 234-249.

Kwon, Y.K. (1989). Accrual versus cash-basis accounting methods: An agency-theoretic comparison. Journal of Accounting and Public Policy, 8(4), 267-281.

Likert, R. (1932). A Technique for the Measurement of Attitudes. Archives of Psychology, 140, 1-55. 
Ortegren, A., \& Reed, B. (1997). Postretirement benefits: The implementation of SFAS No. 106 'versus' accrual accounting in the mining industry. Journal of Accounting Education, 15(2), 289303.

Peng, E.Y. (2011). Accruals quality and the incentive contracting role of earnings. Journal of Accounting and Public Policy, 30(5), 460-480 